\title{
BERSEKOLAH DI TANAH PENGASINGAN: BOVEN DIGUL, 1927-1943
}

\section{Langgeng Sulistyo Budi}

Arsip Nasional Republik Indonesia

Alamat korespondensi: maslanggeng67@gmail.com

Diterima/ Received: 7 Agustus 2017; Disetujui/ Accepted: 31 Oktober 2017

\begin{abstract}
This article discusses implementation on education organized at Boven Digul exile camps during 1927-1943. The discussed issues are about school types which had established in Boven Digul, actors in learning process at these schools, and school's impacts for both camp dwellers and Boven Digul community. By using historical methods with sociological approach. Historical sources used in the method mainly archives and interviews orf oral history. Boven Digul exile camp was founded by the Dutch colonial government and had began operated from 1927 to 1943 . Political prisoners who were exiled in this camp were originally involved in communist uprisings in Banten (West Java) and West Sumatra during 1926-1927. Furthermore, nationalist figures who became prisoners then gradually became camp residents. They even allowed to bring their families. To provide educational needs of exile camps residents, the Dutch colonial government in 1927 established a primary school called Standaardschool, and later became Standaardschool met Nederlandsch. Naturalisten prisoners group allowed to establish a school called Malay English School (MES), which later became a "three family" school held in prisoner's houses. In 1940s students from the "three families" school admitted to Standaardschool, because many teachers switched their profession. They made another living when aid supply declines due to Japanese waters blocaked around Papua. Both Standaardschool, MES and "three families" schools are only for families who belongs to the political prisoners. Therefore, these school's existence did not affect indigenous people around the camp.
\end{abstract}

Keywords: Boven Digul; Education; Camp Exile; Political Prisoners; Papua.

\section{Abstrak}

Artikel ini membahas tentang penyelenggaraan pendidikan di kamp pengasingan Boven Digul pada periode antara tahun 1927-1943. Beberapa persoalan yang akan dibahas dalam artikel ini adalah mengenai jenis sekolah yang didirikan di Boven Digul, para pelaku dalam proses belajar-mengajar di sekolah-sekolah itu, dan dampak dari keberadaan sekolah-sekolah itu baik bagi para penghuni kamp maupun masyarakat Boven Digul. Metode Sejarah dengan pendekatan sosiologis digunakan dalam penelitian ini, dengan sumber berupa arsip dan wawancara. Kamp pengasingan Boven Digul didirikan oleh pemerintah Belanda dan dioperasikan mulai dari 1927 sampai dengan 1943. Tahanan politik yang diasingkan di kamp ini pada awalnya adalah mereka yang terlibat dalam pemberontakan komunis di Banten (Jawa Barat) dan Sumatera Barat pada 1926-1927. Namun, pada tahun-tahun berikutnya para tokoh nasionalis juga menjadi penghuni kamp itu. Para tahanan diizinkan untuk membawa keluarganya. Untuk memenuhi kebutuhan pendidikan di kamp pengasingan, pemerintah kolonial Belanda pada 1927 mendirikan Standaardschool, dan kemudian menjadi Standaardschool met Nederlandsch. Kelompok tahanan naturalisten juga diizinkan untuk mendirikan sekolah bernama Malay English School (MES), yang kemudian menjadi sekolah "tiga keluarga", diadakan di rumah-rumah para tahanan. Pada 1940-an, murid-murid dari sekolah "tiga keluarga" dimasukkan ke Standaardschool, sebab banyak guru yang beralih profesi. Mereka mencari nafkah lain ketika suplai bantuan menurun akibat blokade Jepang terhadap perairan di sekitar Papua. Baik Standaardschool, MES maupun sekolah "tiga keluarga" hanya diperuntukkan bagi keluarga para tahanan politik. Oleh karena itu, keberadaan sekolahsekolah itu tidak memberi pengaruh pada masyarakat asli di sekitar kamp pengasingan.

Kata kunci: Boven Digul;Pendidikan; Kamp Pengasingan; Tahanan Politik; Papua. 


\section{PENDAHULUAN}

Awal abad ke-20 menampakkan kecenderungan yang menarik pada tumbuhnya kesadaran untuk memperjuangkan kebebasan sebuah negeri, yang pada saat itu disebut Hindia Belanda. Perjuangan yang semakin terorganisasi mulai tampak, setelah sebelumnya, pada akhir abad ke-19, ditandai dengan keprihatinan akibat krisis ekonomi. Di Jawa, pada masa krisis itu kondisinya bertambah sulit karena adanya ledakan penduduk. Rakyat Jawa menjadi bertambah miskin. Untuk melawan keresahan itu pemerintah kolonial merancang sebuah kebijakan baru yang mengacu pada pertanggungjawaban Pemerintah Belanda di Hindia Timur, yang kemudian dikenal sebagai Politik Etis (de Jong, 2002:10-11).

Furnivall menyatakan bahwa pada periode kolonial perubahan yang terjadi di negeri jajahan tidak dapat dilepaskan dari keadaan (khususnya politik) negeri induk, yaitu Negeri Belanda. Tahun 1870 merupakan tahun penting bagi perubahan di Hindia Belanda. Liberalisme di bidang ekonomi telah memengaruhi bidang-bidang yang lain. Efisiensi dan kesejahteraan menjadi isu utama (Furnivall, 2009: 240).

Awal abad ke-20 juga merupakan periode kebangkitan bagi banyak negara yang mengalami penjajahan, termasuk Indonesia. Kegetiran hidup di bawah kekuasaan kolonialisme Belanda telah menjadi pengalaman bersama bagi sebagian besar rakyat Indonesia. Seiring dengan berkembangnya nasionalisme Indonesia, kebijakan pemerintah kolonial juga semakin represif.

Pergerakan nasional Indonesia menimbulkan dampak yang tidak menguntungkan bagi pemerintah kolonial. Pada awal abad ke-20 benihbenih nasionalisme Indonesia sudah muncul dan tampak lebih terorganisasi. Radikalisme perlahan tampak ke permukaan. Pada beberapa tahun sebelumnya, pemerintah kolonial disibukkan dengan upaya memadamkan pemberontakan di berbagai daerah. Secara bertahap pemerintah mencari strategi baru untuk meredam radikalisme rakyat Indonesia. Salah satu strategi itu adalah memisahkan para pimpinan pemberontak dari massa pendukungnya dengan mengasingkannya.

Salah satu hal yang menarik dalam sejarah pergerakan bangsa Indonesia, khususnya berkaitan dengan praktik pengasingan, adalah mengenai cara pemerintah kolonial memperlakukan para tahanan politik. Biarpun berstatus sebagai tahanan politik, mereka tetap mendapatkan hak-haknya termasuk dalam bidang pendidikan. Perlu diketahui bahwa mereka berada di kamp pengasingan diikuti oleh anggota keluarganya, dan bahkan ada anak-anak mereka yang lahir di sana.

Sekolah moderen model Barat dirancang sebagai sebuah sistem pendidikan dengan akses terbatas, khususnya bagi kelas-kelas yang memiliki hak istimewa. Sistem persekolahan dibagi menjadi tiga kategori. Pertama, adalah Sekolah Eropa, yang ditujukan bagi anak-anak berkebangsaan Belanda dan anak-anak dari kalangan elite atas masyarakat Indonesia. Kedua, sekolah yang dapat menerima anak-anak bumiputera dari kelas menengah, yang sebagian besar terdiri atas kelompok pegawai negeri sipil dan priyayi. Ada tiga strata sekolah, yaitu Holandsch-Inlandsche School (HIS), Meer Uitgebreid Lager Onderwijs (MULO), dan Algemeene Middelbare School (AMS), yang semuanya menggunakan bahasa pengantar bahasa Belanda. Ketiga, sekolah yang ditujukan bagi masyarakat bumiputera kebanyakan, yang menggunakan bahasa pengantar bahasa Melayu. Kebanyakan murid sekolah kategori ini berasal dari kalangan rendahan bumiputera.

Dalam hubungan itu, dalam artikel ini akan dibahas mengenai penyelenggaraan pendidikan di kamp pengasingan Boven Digul. Pembahasan akan difokuskan pada tiga tema, yaitu bentuk sekolah yang dibangun oleh pemerintah kolonial Belanda di Boven Digul, para pelaku dalam proses belajarmengajar, dan dampak dari model-model pengajaran di Boven Digul.

Keputusan untuk mendirikan kamp pengasingan di Boven Digul muncul dalam sebuah pertemuan luar biasa Raad van Indie (Dewan Hindia Belanda) pada tanggal 18 November 1926 (Hadler, 2010:174). Dengan demikian, keputusan 
tersebut diambil hanya sekitar satu minggu setelah pemberontakan komunis yang diawali di Jawa Barat pada tanggal 12 November 1926 (Shiraishi, 2001: 4).

Pemilihan Boven Digul di kawasan Nieuw Guinea (sekarang: Papua) sebagai lokasi kamp pengasingan juga didukung oleh sebuah organisasi intelejen, yaitu Politieke Inlichtingendienst (PID) (de Jong, 2002: 46), yang bertugas mengawasi berbagai aktivitas politik orang-orang Indonesia. Rekomendasi PID dapat memengaruhi keputusan Gouverneur Generaal (GG) untuk mengirimkan seseorang ke kamp pengasingan.

Strategi pembuangan mulai diintensifkan setelah terjadinya pemberontakan komunis pada tahun 1926-1927. Ratusan orang (dari sekitar 13.000 orang yang ditangkap karena dituduh terlibat dalam pemberontakan itu) diasingkan ke Boven Digul (de Jong, 2002: 20).

Pada awal tahun 1927 rombongan pertama tahanan politik tiba di Boven Digul. Tahun itu sekaligus dijadikan batas awal pembahasan dalam studi ini. Sejak saat itu nasib mereka yang memberontak pada pemerintah kolonial mulai dapat ditebak, yaitu dihukum berat atau diasingkan. Ke mana mereka akan diasingkan sudah ditentukan pada rapat para petinggi Hindia Belanda. Batas akhir kajian ini adalah tahun 1943. Pada tahun itu van der Plas memutuskan untuk memindahkan para tahanan politik ke Australia. Pemindahan itu dilakukan karena Belanda merasa khawatir bahwa para tahanan politik itu akan dibebaskan oleh Jepang (Kahin, 1990:158).

\section{METODE}

Upaya untuk merekonstruksi sistem persekolahan di kamp pengasingan Boven Digul pada periode 1927-1943 didahului dengan heuristik. Hal ini karena proses penulisan sejarah tidak mungkin dilakukan tanpa tersedianya sumber-sumber sejarah (Pranoto, 2010: 30). Sumber-sumber yang digunakan dalam penelitian ini terdiri atas sumber tertulis dan sumber lisan. Seperti disarankan oleh Pranoto (2010: 20), penulisan sejarah sedapat mungkin mengutamakan penggunaan sumbersumber primer (primary sources), yaitu sumbersumber yang menyajikan informasi tangan pertama mengenai peristiwa yang dikaji.

Sumber utama kajian ini adalah arsip-arsip yang tersimpan dengan baik di Arsip Nasional Republik Indonesia (ANRI). Informasi tentang kamp pengasingan Boven Digul dan kehidupan para penghuninya dapat dibaca dalam Arsip Boven Digoel. Dalam khasanah arsip ini terdapat informasi tentang jumlah dan aktivitas para tahanan politik serta keluarga mereka. Dalam khasanah arsip milik Departement van Binnenlandsch Bestuur (Departemen Dalam Negeri) juga ditemukan beberapa nomor yang memuat informasi tentang kamp Boven Digul, khususnya berkaitan dengan konteks administrasi daerah tersebut. Sumber tertulis lain yang digunakan adalah surat kabar dan majalah sezaman yang diperoleh dari Perpustakaan Nasional Republik Indonesia. Reportase dalam surat kabar dan majalah sezaman memuat berbagai isu yang berkaitan dengan kamp Boven Digul.

Di samping sumber-sumber tertulis, dalam penelitian ini juga digunakan sumber lisan yang diperoleh melalui wawancara sejarah lisan dengan para pelaku atau saksi dalam peristiwa sejarah yang dikaji. Melalui metode ini dapat digali pengalaman orang-orang biasa sekaligus diperoleh berbagai informasi yang berguna untuk melengkapi atau mengatasi keterbatasan informasi dalam sumbersumber tertulis (Roosa dan Ratih, 2008: 177). Metode sejarah lisan juga dapat mengungkap halhal yang unik dalam pengalaman para pengisah. Hal ini karena manusia pada dasarnya memiliki kebebasan untuk mengarahkan aktivitasnya sesuai dengan tuntutan akalnya. Karakter setiap orang dapat berbeda, sehingga pemaknaan atas peristiwa sejarah yang mereka alami juga dapat berbedabeda. Sudah barang tentu, usaha mengumpulkan sumber lisan melalui wawancara sejarah lisan menghadapi kendala, terutama berkaitan dengan usia para pengisah yang telah lanjut.

Sumber-sumber yang telah dikumpulkan itu kemudian dikritik secara eksternal dan internal. 
Kritik eksternal dilakukan untuk memeriksa otentisitas sumber, sedangkan kritik internal bertujuan untuk mendapatkan fakta-fakta sejarah yang kredibel (Pranoto, 2010: 37). Fakta-fakta itu selanjutnya diinterpretasi dan dieksplanasikan dalam sebuah ikatan peristiwa yang disusun berdasar prinsip kronologis dan kausalitas. Dengan kedua prinsip tersebut, artikel ini diharapkan dapat mengungkapkan secara deskriptif-analitis tentang kehidupan tahanan politik di kamp Boven Digul, dan sekaligus menjawab pertanyaan "bagaimana" dan "mengapa" peristiwa itu terjadi (Kartodirdjo, 1993: 93-94).

\section{HASIL DAN PEMBAHASAN}

Usaha untuk menjaga keamanan dan ketertiban di wilayah di Hindia Belanda, yang diikuti dengan kebijakan pengasingan, tidak serta-merta memberi hukuman fisik saja kepada para tahanan politik dan keluarganya. Jaminan hidup dan kesempatan untuk mendapatkan pendidikan juga diberikan kepada mereka di tanah pengasingan, walaupun pada tingkatan yang paling minimal. Untuk memenuhi kebutuhan para penghuni kamp dalam mendapatkan informasi dan ilmu pengetahuan, pemerintah mendirikan sebuah sekolah formal bagi anak-anak para tahanan politik di Boven Digul. Pemerintah juga memberi izin kepada kelompok tahanan tertentu untuk mendirikan dan mengelola sekolah mereka sendiri.

Dengan demikian, ada dua macam sekolah di kamp Boven Digul, yaitu sekolah yang didirikan oleh pemerintah lengkap dengan semua sarananya, dan sekolah yang didirikan oleh para tahanan, khususnya kelompok naturalisten. Dalam perkembangan, sekolah formal yang didirikan oleh para tahanan harus berhadapan dengan kebijakan keras pemerintah ketika mereka dianggap tidak mendukung upaya mempertahankan keamanan dan ketertiban. Akibatnya, muncul kelompokkelompok belajar di lingkungan kamp, yang disebut sekolah "tiga keluarga".

\section{Standaardschool}

Sejak November 1927 di kampung A didirikan sekolah baru. Sekolah ini mempunyai murid 200 orang (Kartomi, 2005:53). ${ }^{1}$ Sekolah itu mendapat subsidi dari pemerintah sebanyak f 2000,- per tahun. Tenaga pengajarnya ada 4 (empat) orang, yang semuanya mantan murid kweekschool namun belum lulus. Ada juga seorang guru perempuan.

Sampai pada 1930 -an, para mantan murid standaardschool masih mengenang peranan seorang guru yang berasal dari Sumatera Barat, yaitu Soetan Said Ali. Dia dikenal sebagai kepala sekolah yang profesional dan disiplin. ${ }^{2}$ Nama Soetan Said Ali juga disebut dalam laporan pemerintah Belanda, yang berkaitan dengan alasan pembuangannya ke Boven Digul. ${ }^{3}$ Sehari-hari Said Ali dibantu oleh beberapa guru tidak tetap, antara lain: Moestadjab, Jahja Nasoetion, ${ }^{4}$ dan Soejitno Hadiwirjo. ${ }^{5}$ Pada 1932, Said Ali dan istrinya mendapat gaji dari pemerintah sebesar f. $60 .^{6}$

Masa belajar di Standaardschool adalah tujuh tahun. Sekolah ini pada tahun 1930 berubah nama menjadi Standaardschool met Nederlandsch, dengan bahasa pengantar bahasa Belanda. Jam belajar di sekolah ini dimulai pada pukul 07.00 dan berakhir pada pukul 13.00, dari hari Senin sampai dengan Sabtu, dengan waktu istirahat dua kali. Mata pelajaran yang diajarkan di sekolah ini sama dengan sekolah setingkat Hollandsch Inlandsche School (HIS) (Aritonang, 1988:21-22). ${ }^{7}$ Ada sebuah perpustakaan yang memiliki 700 buku. Pada tahun itu pemerintah sedang mengusahakan untuk mengadakan pendidikan di Tanah Tinggi. ${ }^{8}$ Dengan demikian, lembaga pendidikan yang ada di kawasan kamp Boven Digul adalah lembaga pendidikan tingkat dasar.

Standaardschool diperuntukkan bagi muridmurid bumiputera terutama dari kalangan rendah seprti petani dan buruh. Anak-anak bumiputera dari keluarga tokoh terkemuka dan orang terhormat akan dimasukkan ke sekolah dasar kelas satu (de scholen der eerste klasse) (Panyarikan, 
1996:35; Staatsblad van Nederlandsch-Indie 1893 No. 125).

Tujuan pendidikan di Standaarschool adalah agar anak-anak dari kalangan penduduk bumiputera dapat membaca, menulis, mengenal huruf Latin, berhitung, dan kadang-kadang menggambar. Bahasa pengantarnya adalah bahasa Melayu. Pelajaran diberikan paling sedikit dalam waktu tiga jam sehari. Jika pelajaran agama akan diberikan, maka waktunya harus diperpanjang (Panyarikan, 1996:37; Staatsblad van Nederlandsch-Indie 1906 No. 241).

Pelajaran sejarah Indonesia diberikan secara terbatas, yaitu berkisar pada beberapa kerajaan besar saja. Pelajaran sejarah yang diberikan adalah sejarah dunia. Buku-bukunya menggunakan bahasa Belanda. Salah seorang tahanan melaporkan hasil perjalanannya mengelilingi kawasan Tanah Tinggi kepada het Hoofd van Plaatselijk Bestuur te Tanah Merah. Saat berkeliling, ia menjumpai dua kelas yang masingmasing sedang diajar oleh Sardjono (Stb. No. 8) dan Kasmoeni (Stb. No. 46). Di kelas Sardjono ada sembilan orang murid, sedangkan di kelas Kasmoeni ada delapan orang murid. Namun, ia tidak mengetahui mata pelajaran apa yang sedang diajarkan oleh kedua orang guru itu.

Murid Standaardschool tidak dipungut biaya. Siapa pun yang berasal dari keluarga tahanan politik dapat bersekolah di sekolah itu. Selama sekolah itu beroperasi, tidak ada satu pun penduduk asli dan anak-anak pejabat birokrasi ( $B B$ ambtenaar atau Bestuurtrerrein) yang bersekolah di situ. Keluarga $B B$ ambtenaar bersekolah di sekolah yang ada di lingkungannya. Ijazah akan diberikan pada akhir tahun pelajaran kelas VII. Ulangan umum diadakan pada setiap semester. Nilai dalam rapport ditulis dalam skala 0-10.

Sekolah yang didirikan oleh pemerintah di kawasan kamp Boven Digul hanya untuk keluarga tahanan politik. Kehadiran Standaardschool di kamp itu tidak banyak berpengaruh pada penduduk lokal. Sekolah pemerintah ini dari tahun ke tahun selalu memiliki murid, tetapi jumlahnya sering berubah. Perubahan jumlah murid itu sangat terkait dengan perubahan status tahanan orang tua mereka. Pengalaman Trikoyo menunjukkan bahwa dia dapat bersekolah di Standaardschool setelah orang tuanya bekerja untuk kepentingan pemerintah atau bukan masuk kategori naturalist lagi. Pengalaman lain juga dialami oleh Chamsinah (dalam arsip sering ditulis Kamsinah), yang masuk Standaardschool setelah di Tanah Merah model sekolah di rumah tidak berjalan lagi, khususnya setelah Tanah Merah mulai kacau menjelang kedatangan Jepang.

Pada periode akhir kamp Boven Digul, para guru yang sebelumnya mengajar di sekolahsekolah rumahan sudah mulai kesulitan mendapatkan bantuan. Kapal-kapal Belanda yang biasa membawa logistik atau bahan pangan, yang sebelumnya berlabuh di dermaga Tanah Merah sebulan sekali, sudah tidak teratur berlayar ke kawasan Boven Digul. Kebanyakan dari mereka, yang naturalisten maupun yang menggantungkan pada bantuan pemerintah, mencari penghidupan lain.

Kondisi yang demikian memaksa para orang tua untuk memindahkan anak-anaknya ke sekolah lain. Sekolah yang masih terus berdiri adalah sekolah milik pemerintah atau Standaardschool. Sekolah ini terus ada dan terus beraktivitas sampai menjelang balatentara Jepang memasuki kawasan Boven Digul. Kebutuhan hidup para tahanan dan seluruh staf administrasi Pemerintah Belanda di Boven Digul sebelum diungsikan dipenuhi oleh Pasukan Sekutu.

Kondisi yang mulai darurat itu tetap membutuhkan sebuah sekolah yang harus terus beroperasi. Syarat usia sekolah (pada tahun 1939, misalnya) juga menjadi sangat longgar. Untuk kelas persiapan, usia murid yang dapat diterima berkisar antara 4-8 tahun. Usia murid di kelas I berkisar antara 6-9 tahun. Batasan usia di setiap kelas tidak sama. Berdasar kesaksian Chamsinah, hal itu mungkin saja terjadi karena murid-murid yang berasal dari sekolah-sekolah "tiga keluarga" yang berpindah ke Standaardschool dianggap harus duduk di kelas yang lebih rendah dibandingkan usia sekolahnya. Bisa saja anak yang 
berusia delapan tahun harus kembali ke kelas persiapan, karena standar pengetahuannya belum memenuhi syarat baginya untuk masuk di kelas I. Hal yang sama terjadi juga untuk kelas-kelas yang lain.

Proses perpindahan sekolah dari "sekolah liar” ke sekolah formal milik pemerintah (Standaardschool) atau sebaliknya tidak terlalu sulit. Semuanya sangat tergantung dari status tahanan orang tua masing-masing murid.

Saat itu Standaardschool masih aktif mengadakan kegiatan belajar-mengajar. Hanya Kelas V yang tidak memiliki murid. Komposisi itu berubah pada 1941, setelah keadaan di Boven Digul mulai bertambah kacau. Kelas VII tidak memiliki murid, namun Kelas $\mathrm{V}$ sudah ada muridnya. Sekolah yang ada tinggal Standaardschool met Nederlandsch.

\section{Malay English School(MES)}

Setelah 1929, banyak anak kaum naturalisten yang ditarik ke luar dari sekolah pemerintah, dan dimasukkan ke sekolah yang mereka dirikan (Bondan, 2008:192). Sekolah ini dikenal dengan nama Malay-English School (MES). Dalam standar sekolah Eropa, MES sangat tidak memenuhi syarat, apalagi dari sisi sarana pengajaran. Sekolah ini tidak berjalan lama, sebab setelah terjadinya penggrebekan oleh polisi, sekolah tersebut ditutup. Aktivitas belajarmengajar dipindahkan di rumah-rumah penghuni kamp. ${ }^{9}$

Setelah MES dibubarkan, maka pengajaran dijalankan berdasar sistem "tiga keluarga". Artinya, dalam praktik pengajaran sehari-hari hanya ada empat orang yang hadir pada setiap pelajaran, yaitu satu guru dan anak-anak dari tiga keluarga (Bondan, 2008:190).

Para tahanan tidak ingin memasukkan anakanak mereka ke sekolah pemerintah, sebab sekolah pemerintah dianggap terlalu berorientasi pada kepentingan kolonial. Hatta menyebut tujuan sekolah pemerintah adalah agar anak-anak di kemudian hari menjadi hamba Ratu Belanda dan pandai menyanyikan lagu kebangsaan Belanda (Bondan, 2008:190).

Aktivitas MES akhirnya diketahui oleh pemerintah, dan akibatnya para guru harus mengajar dengan pengawasan yang ketat. Oleh karena itu, tidak jarang ada guru yang ditahan karena dianggap mengganggu keamanan dan ketertiban. Bukan saja karena masalah materi pelajaran seorang guru bisa ditahan, tetapi apabila dia mengajar lebih dari tiga orang juga bisa ditahan (Bondan, 2008: 192). ${ }^{10}$

Pelajaran yang diberikan di Kelas III MES adalah pelajaran standar sekolah dasar. Pelajaranpelajaran terdiri atas ilmu bumi dunia, fisika, kosmografi, biologi, matematika, bahasa Melayu, dan bahasa Inggris. Buku-buku dibawa dari Jawa; kecuali untuk pelajaran bahasa Inggris yang menggunakan buku Royal Science Readers I-VI dan Elementary Grammar, yang semuanya dipesan dari Inggris (Bondan, 2008: 192).

Keberadaan sekolah-sekolah model ini ternyata mendapatkan perhatian dan pengawasan pemerintah. Dalam laporan yang dibuat pada 1941 disebutkan bahwa sekolah-sekolah ini dikenal mandiri dalam pengelolaannya. Sekolah ini dikelola oleh para tahanan atau tidak disubsidi oleh pemerintah atau dimasukkan ke dalam ketegori “wilde scholen” ( sekolah-sekolah liar).

Keberadaan sekolah-sekolah liar tidak luput dari pengawasan pemerintah. Orang-orang yang mengajar di sekolah-sekolah jenis ini dianggap memiliki tingkat intelektualitas yang lebih tinggi dibandingkan dengan para tahanan yang lain. Hatta dan Syahrir, misalnya, dianggap memiliki pengetahuan yang lebih baik dibandingkan para tahanan yang lain karena, khususnya Hatta, memiliki akses yang lebih baik terhadap informasi dan ilmu pengetahuan. Hatta dan Syahrir bisa membawa dan mendapatkan buku-buku maupun majalah, sehingga mereka memiliki murid di rumah masing-masing. Hatta dan Syahrir dianggap berbahaya, karena mengajar para tahanan untuk bersikap kritis. Akibatnya, keduanya dipindahkan ke tempat pengasingan yang lain, yaitu Banda 
Neira. Model sekolah ini terus dilanjutkan pada periode berikut, dengan kontrol yang tetap ketat.

Dalam laporan pemerintah, sekolah-sekolah yang diadakan di rumah-rumah tahanan disebut sebagai wilde school atau sekolah liar. Pada awalnya "Ordonansi Sekolah Liar" dikenal dengan Toezicht Ordonantie Particulier Onderwijs (Ordonansi Pengawasan atas Pendidikan Swasta), yang dimuat dalam Staatsblad 1932 No. 494. Pendidikan Swasta dalam aturan tersebut diartikan sebagai pendidikan yang tidak disubsidi oleh pemerintah (het particulier ongesubsidieerde onderwijs). Sekolah model ini berkembang sangat pesat sejak tahun 1930. Selain disebabkan oleh adanya pemotongan anggaran pemerintah untuk pendidikan, berkembangnya sekolah itu juga berkaitan dengan tingkat pengangguran di kalangan cendekiawan, sehingga kebanyakan dari mereka mencari nafkah dari mengajar (Tsuchiya, 1992: 262).

Pengawasan terhadap sekolah liar sudah dilaksanakan sejak tahun 1922, ketika Gubernur Jenderal Fock menerima laporan dari J.F.W. van der Meulen selaku Direktur Pendidikan dan Peribadatan Umum (Directeur van Onderwijs en Eredienst) tentang sekolah-sekolah Cina, Sekolah Sarekat Islam di Semarang, dan Sekolah Latihan Guru yang dibuka oleh Soewardi Soerjaningrat di Yogyakarta, sekolah himpunan pendidikan pribumi Perserikatan Goeroe Hindia Belanda (PGHB), Pergoeroean Ra'jat, dan beberapa sekolah yang bermotif ekonomi di Minahasa dan Padang (Groeneboer, 1995: 360). Sekolahsekolah Cina dianggap mengajarkan nasionalisme Cina, sedangkan sekolah-sekolah di Semarang dan Yogyakarta dianggap mengajarkan pendidikan anti-sosial, sehingga pemerintah harus mengawasi para gurunya. Pemerintah menyebut sekolahsekolah itu sebagai sekolah liar swasta (wilde particuliere schooltjes). Sejak 1 Januari 1925, van der Meulen menyebut sekolah Cina, sekolah Sarekat Islam, dan sekolah Sarekat Rakyat (di Purbolinggo, Purwokerto, dan Jatinegara) sebagai sekolah liar, termasuk juga sekolah Taman Siswa dan sekolah Ardjuna (Tsuchiya, 1992: 262-263).
Di tengah-tengah pemberlakuan kebijakan penghematan anggaran pendidikan, pemerintah kolonial Belanda menghapuskan bahasa Belanda sebagai bahasa pengantar di tiga kelas terendah di HIS. Di sisi lain, sekolah-sekolah swasta yang masuk kategori liar pada umumnya menggunakan kurikulum HIS yang lama dengan menggunakan bahasa Belanda sebagai bahasa pengantar sejak kelas satu (Groeneboer, 1995: 361). Sekolahsekolah rumahan model "tiga keluarga" yang dikembangkan oleh para tahanan di Boven Digul adalah sekolah-sekolah yang tidak mendapat subsidi sedikit pun dari pemerintah. Pemerintah kolonial Belanda menyebut sekolah-sekolah itu sebagai sekolah liar.

\section{Peserta Didik}

Aktivitas di Standaardschool kadang-kadang juga melibatkan para tahanan. Ada beberapa tahanan yang memiliki kemampuan berbahasa Belanda dan Inggris, sehingga mereka dapat mengajar di kelaskelas yang ada di kamp (Lockwood, 1983: 29). Pada saat jam pelajaran bahasa Belanda dan bahasa Inggris bagi orang-orang dewasa, ada juga tahanan dewasa yang mengikutinya, termasuk menjadi penyelenggaranya.

Dalam laporan kwartal ke dua tahun 1939 disebutkan ada 10 orang guru dari kalangan naturalisten. Mereka mengajar 49 orang murid yang terdiri atas 30 orang laki-laki dan 19 orang perempuan. Guru-guru yang dimaksud adalah: Djojodoelkadir (tiga orang murid), Moeljani (dua orang murid), Oerip Asnawi (tiga orang murid), Zainoel Abidin (tiga orang murid), Adenin (delapan orang murid), Mawengkang (delapan orang murid), Pasiran (dua orang murid), Chamim (dua orang murid), Harjono (satu orang murid), dan Soetasalekan (dua orang murid). Pengajaran diberikan di beberapa rumah penghuni kamp, baik di rumah pengajarnya maupun orang tua dari salah satu murid. ${ }^{11}$ Komposisi pengajar dan jumlah murid itu berubah pada kwartal ke empat tahun 1939. Data yang terperinci adalah: Wirjodihardjo (empat orang murid), Sadi 
Singomentolo (dua orang murid), Zanoel Abidin (tiga orang murid), Adenin (tujuh orang murid), Mawengkang (empat orang murid), Pasiran (dua orang murid), Chamim (dua orang murid), dan Slamat (dua orang murid). Dalam laporan itu disebutkan bahwa pengajaran ini masuk dalam kategori standaardschool, dengan jumlah murid 52 orang yang terdiri atas 32 orang laki-laki dan 20 orang perempuan. Tidak dijelaskan mengapa komposisi pengajar dan murid berubah, selain informasi bahwa murid, pengajar, dan tempat belajar berasal dari kalangan naturalisten.

Kadarisman memiliki 22 orang murid, yang terdiri atas Kelas I (empat orang), Kelas II (12 orang), Kelas V (tiga orang), dan yang mengikuti pelajaran siang (tiga orang). ${ }^{12}$ Pada 1940 jumlah muridnya menjadi 23 orang, dengan tambahan Darsono pada bagian pelajaran siang. Jumlah itu tetap sama sampai 31 Maret 1940. Ada orang lain yang mengikuti jejak Kadarisman, yaitu Abdul Qodir. Ia memiliki delapan orang murid yang semuanya para tahanan. Kadarisman juga memberikan kursus malam dengan jumlah murid 6 (enam) orang di Kelas I, dua orang di Kelas II, tujuh orang di Kelas III, dan dua orang di Kelas V.

Standaardschool yang ada memiliki 52 orang murid yang 28 orang laki-laki dan 24 orang perempuan. Di antara mereka ada yang berasal dari keluarga naturalisten. Jumlahnya 11 orang murid, yaitu: Matsari (satu orang laki-laki dan satu orang perempuan), Prijokoesoemo (satu orang laki-laki dan satu orang perempuan), T. Boedjang (dua orang laki-laki), Prawirodikromo (satu orang laki-laki dan dua orang perempuan), Soerodirono (satu orang laki-laki), Amat Saleh (satu orang perempuan). Rincian jumlah murid standaardschool adalah: Kelas I berjumlah 12 orang murid, Kelas II berjumlah 11 orang murid, Kelas III berjumlah lima orang murid, Kelas IV berjumlah tujuh orang murid, Kelas V berjumlah 2 orang murid, Kelas VI berjumlah empat orang murid, dan kelas persiapan berjumlah 11 orang murid. ${ }^{13}$ Berdasar laporan yang dibuat oleh kepala kampong (het kamponghoofd) pada 31 Maret 1941, standaardschool itu dikategorikan standaardschool met Nederlandsch karena menggunakan bahasa Belanda sebagai bahasa pengantar. ${ }^{14}$

Pada kwartal ke dua tahun 1939 terdapat 1012 orang tahanan yang terlibat dalam upaya memberikan pengajaran kepada anak-anak tahanan. ${ }^{15}$ Jumlah murid mereka pada kurun waktu yang sama sekitar 34 orang. Pengajarnya adalah para naturalisten.

Berdasar sumber yang sama diperoleh rincian jumlah murid standaardschool sampai akhir kwartal kedua tahun 1939, yaitu: 30 orang murid laki-laki dan 19 murid perempuan, sehingga jumlah keseluruhannya adalah 49 orang murid. Jumlah itu mencakup seluruh murid dari tingkat persiapan sampai pada Kelas VII. Jumlah murid sampai kwartal ketiga tahun 1939 adalah 49 orang, yang terdiri atas 30 orang murid laki-laki dan 19 murid perempuan. ${ }^{16}$ Pada kwartal keempat tahun 1939 jumlah muridnya menjadi 52 orang, yang terdiri atas 32 orang murid laki-laki dan 20 orang murid perempuan. Jumlah pengajarnya berjumlah 12 orang. ${ }^{17}$ Pada akhir kwartal pertama tahun 1940 jumlah murid adalah 51 orang, meliputi 31 orang murid laki-laki dan 20 orang murid perempuan. Mereka diajar oleh 13 orang pengajar. ${ }^{18}$ Jumlah murid Standaardschool met Nederlandsch adalah 47 orang, yang terdiri atas 29 murid laki-laki dan 18 orang murid perempuan. Pada kwartal ketiga, jumlah murid sekolah jenis itu menjadi 49 orang, tediri atas 29 orang murid laki-laki dan 20 orang murid perempuan. Jumlah itu berubah pada 1940 kwartal keempat, yaitu menjadi 51 orang yang terdiri atas 29 murid laki-laki dan 23 murid perempuan.

Pada kwartal kedua 1940, murid wilde schoolen (sekolah liar) berjumlah 20 orang. Mereka diajar oleh sekitar 13 orang guru. ${ }^{19}$ Pada kwartal pertama tahun 1941 jumlah murid sekolah liar adalah 23 orang, yang terdiri atas 10 orang murid laki-laki dan 13 orang murid perempuan. Pada kwartal kedua jumlah muridnya menjadi 24 orang, meliputi 11 orang murid laki-laki dan 13 orang murid perempuan. Mereka diajar oleh 10 orang guru. Pada kwartal ketiga tahun yang sama, 
jumlah muridnya menjadi 21 orang. Mereka terdiri atas 10 orang murid laki-laki dan 11 orang murid perempuan, dan diajar oleh sembilan orang guru. Pada kwartal keempat jumlah muridnya tinggal 16 orang, yang terdiri atas delapan orang murid lakilaki dan delapan orang murid perempuan. ${ }^{20}$

Walaupun para tahanan mendapatkan banyak kebebasan untuk mengenyam pendidikan, namun pemerintah kolonial Belanda sebenarnya masih menerapkan pengawasan yang cukup intensif. Dalam setiap kali tugas jaga malam yang dilakukan oleh para tahanan sendiri, aparat selalu meminta tahanan untuk mengontrol keberadaan sekolah liar di kawasan itu. ${ }^{21}$

Perbedaan alasan untuk memasukkan anakanak ke salah satu dari dua jenis sekolah tersebut di atas sering kali longgar. Seorang murid dengan alasan bisa pindah dari sekolah yang dikelola kelompok naturalisten ke sekolah pemerintah. Trikoyo, misalnya, ketika ayahnya masih berstatus naturalis, pada usia tujuh tahun dia bersekolah di MES. Beberapa tahun kemudian dia pindah ke standaardschool, karena ayahnya sudah tidak lagi berstatus naturalis. Di sekolah ini bahasa pengantarnya adalah bahasa Belanda. Tidak ada uang sekolah dan seragam di sekolah milik pemerintah ini. Pelajaran dimulai pada jam 07.0013.00, dari hari Senin-Sabtu. Lama belajar di standaardschool ini adalah tujuh tahun. ${ }^{22}$

Ketika masih bersekolah di sekolah tiga keluarga, Trikoyo harus merasakan belajar di rumah-rumah sesama tahanan yang mengadakan kegiatan belajar-mengajar. Dia masih ingat bahwa guru-guru yang mengajar adalah sesama tahanan yang memiliki latar belakang pendidikan guru sewaktu belum diasingkan ke Boven Digul. Bahasa pengantar di sekolah ini adalah bahasa Melayu, dan ada pelajaran Bahasa Inggris.

\section{Kemampuan Baca dan Bahasa}

Pendidikan yang dipraktikkan di Boven Digul sebagian besar dilaksanakan berdasar model Barat. Bahasa pengantar, kurikulum, dan buku ajar dikembangkan oleh Belanda. Baik di sekolah pemerintah maupun sekolah liar, penggunaan bahasa dapat dikatakan seimbang antara bahasa Melayu dan bahasa asing (bahasa Belanda dan bahasa Inggris). Penguasaan bahasa menjadi persyaratan penting, sebab buku ajarnya sebagian besar berbahasa asing. Dengan demikian muridmurid di sekolah pemerintah maupun sekolah liar tidak saja melek huruf, tetapi juga melek bahasa asing, khususnya bahasa Belanda dan bahasa Inggris.

Bahasa Belanda akhirnya menjadi pintu gerbang menuju Barat, sebab mayoritas buku teks pelajaran ditulis dalam bahasa Belanda (Groeneboer, 1995: 229). Di daerah-daerah lain, akses ke sekolah-sekolah yang menggunakan bahasa Belanda sebagai bahasa pengantar mungkin sangat terbatas. Namun, di Boven Digul, semua orang yang pernah duduk di bangku sekolah, baik di sekolah pemerintah maupun sekolah liar, mampu menguasai bahasa Belanda. Pembatasan yang didasarkan pada status sosial dalam menguasai bahasa asing, khususnya bahasa Belanda, menjadi hilang di Boven Digul.

Dalam kehidupan sehari-hari bahasa Melayu dan bahasa Jawa menjadi bahasa pergaulan yang paling banyak digunakan. Bahasa Jawa banyak terdengar, karena sebagian besar penghuni kamp adalah orang Jawa. Bahasa Melayu mampu menyatukan perbedaan bahasa daerah di antara para penghuni kamp. Bahasa Melayu juga diajarkan dalam pergaulan dengan penduduk asli Indonesia.

Pemakaian bahasa Melayu pada periode pergerakan merupakan simbol penyatuan tekad. Bahasa Melayu tidak terikat suku dan status serta tidak memiliki masalah hierarkhi. Walaupun tumbuh di daerah Sumatera, bahasa Melayu membantu penduduk maupun pemimpin dalam berkomunikasi lintas-suku. Oleh karena itu, Elson menyatakan bahwa penggunaan bahasa Melayu sebagai bahasa pergaulan merupakan pertanda tumbuhnya keyakinan akan Indonesia (Elson, 2009: 98-99). 


\section{Semangat Kebangsaan}

Perkembangan politik di Indonesia tidak pernah diajarkan secara formal. Pelajaran tentang kebangsaan muncul dalam pendidikan dalam keluarga atau di luar sekolah formal, walaupun pengajar di sekolah formal adalah orang-orang Indonesia. Hal itu terjadi sebagai akibat dari adanya kontrol pemerintah yang ketat.

Pendidikan agama diberikan di lingkungan keluarga. Kurikulum sekolah formal pemerintah tidak mengalokasikan jam pelajaran agama. ${ }^{23} \mathrm{Hal}$ itu bisa dimaklumi, karena sebagian besar tahanan memiliki latar belakang tokoh atau ahli agama Islam di daerahnya.

Nilai-nilai kebangsaan jelas tidak dapat diharapkan dari pelajaran di sekolah formal atau di standaardschool. Cerita tentang bagaimana mereka bisa sampai Boven Digul dan dalam konteks apa mereka sampai ke Boven Digul hanya muncul dalam pembicaraan di dalam keluarga. Semua orang yang berstatus tahanan tentu memiliki alasan yang sama mengapa mereka sampai di tempat terpencil itu, yaitu karena aktivitas orang tuanya dianggap membahayakan stabilitas politik pemerintah kolonial Belanda. Anak-anak yang segenerasi dengan Trikoyo dan Chamsinah mendapatkan informasi tentang status mereka dari keluarga dan lingkungan sesama tahanan. ${ }^{24}$

Pewarisan nilai-nilai kebangsaan dalam bentuk perlawanan tidak keluar dalam bentuk verbal "lawan", namun tampak dalam kehidupan sehari-hari. Mereka bisa sampai ke Boven Digul karena sikap perlawanan itu. Demikian pula ketika orang tua mereka memilih untuk tetap menjadi naturalis, juga menjadi simbol perlawanan.

Sikap menentang atau anti-Belanda itu masih tampak sampai mereka keluar dari Boven Digul. Paling tidak hal itu dapat dilihat dari pengalaman Trikoyo dan Chamsinah. Ketika Trikoyo keluar dari Boven Digul, dia memilih ikut pamannya yang bekerja di perusahaan perkebunan Jepang. Pada masa pendudukan Jepang, Trikoyo masuk ke sekolah militer Jepang di Kalimantan Utara sampai lulus. Ketika Jepang kalah, Trikoyo bersama 40 orang eks-Heiho yang berasal dari Jawa melarikan diri ke Kalimantan Barat. Pasukan ini menjadi kekuatan untuk melawan Sekutu dan Belanda di Kalimantan Utara. Di sisi lain, Chamsinah adalah satu dari ratusan orang tahanan politik yang diungsikan ke Australia. Ia mendapat kesempatan untuk menempuh pendidikan di sana. Ketika diminta masuk ke sekolah perawat dengan janji akan dipekerjakan di rumah sakit Belanda di Hollandia, dia memilih untuk ke luar dari sekolah itu.

\section{SIMPULAN}

Kehadiran anak-anak dari keluarga tahanan politik di standaardschool sangat bergantung pada status tahanan yang disandang oleh orang tua mereka. Ketika orang tua mereka dianggap mau bekerja sama dengan pemerintah kolonial, maka dapat dipastikan bahwa anak-anaknya akan mendapat fasilitas bersekolah di standaardschool. Siapa saja yang boleh mengajar di sekolah itu juga diseleksi oleh pemerintah. Kesetiaan kepada pemerintah masih menjadi kriteria utamanya.

Peranan bahasa Melayu dan bahasa Jawa dalam pergaulan di lingkungan kamp sangat penting. Komunikasi dan pembicaraan tentang nasib mereka di tanah seberang berjalan lancar melalui kedua bahasa tersebut. Bahasa Belanda dan bahasa Inggris yang mereka dapatkan melalui sekolah tidak digunakan sebagai bahasa pergaulan sehari-hari. Komunikasi dengan para pejabat pemerintah, khususnya para pejabat bumiputera, juga berlangsung dengan menggunakan bahasa Melayu. Penduduk asli secara perlahan kemudian juga belajar bahasa Melayu untuk berkomunikasi dengan penghuni kamp, menggantikan bahasa isyarat yang sebelumnya selalu mereka gunakan. ${ }^{25}$

Kehidupan di tanah pengasingan menjadi pengalaman yang memprihatinkan dan begitu membekas bagi para tahanan. Aspirasi politik jelas tidak tersalurkan. Namun, jika dicermati, rupanya telah terjadi proses integrasi yang paling sederhana 
baik bentuknya maupun makna yang dipahami oleh para tahanan dan keluarganya.

Harus dipahami bahwa integrasi bukan merupakan barang jadi, namun sebuah proses historis. Interaksi adalah proses awal sebagai dasar bagi pengembangan solidaritas. Menurut Kartodirdjo, bagian akhir dari proses ini adalah terbentuknya sebuah wadah atau organisasi yang berfungsi sebagai tumpuan identitas sosial, kultural, dan akhirnya politik (Kartodirdjo, 1990: 125).

Dalam kehidupan sehari-hari di kamp pengasingan, hubungan antarpenghuni menjadi lebih cair. Mereka dapat lebih saling mengenal. Sekolah sistem tiga keluarga ikut membuat mereka merasa menjadi satu kesatuan. Ada kesadaran bahwa mereka berada di tempat pengasingan itu karena masalah yang sama, yaitu berupaya melawan dominasi kolonial dan oleh karenanya mereka dianggap sebagai musuh pemerintah.

Penggunaan bahasa Belanda sebagai bahasa pengantar dalam dunia pendidikan ternyata tidak mampu menjadikan penghuni kamp sebagai "Belanda". Cita-cita perlawanan masih ada dalam diri mereka. Pengalaman hidup di Boven Digul telah memampukan mereka untuk beradaptasi dan berinteraksi dengan sesama tahanan. Pengajaran dan persekolahan yang ada, khususnya yang diadakan oleh sesama tahanan, ternyata dapat melampaui perbedaan suku, ideologi, dan agama, sehingga terjadi interaksi yang diikuti dengan terbangunnya solidaritas di antara tahanan politik. Mereka memiliki musuh bersama, yaitu kolonialisme. Pada tingkat yang paling sederhana, solidaritas itu menyatukan ide mereka tentang keindonesiaan. Persepsi dan ikatan itu rupanya menjadi kekuatan yang menakutkan bagi pemerintah kolonial. Oleh karena itu, ketika Belanda menyerah kepada bala tentara Jepang dan harus mengungsi ke Australia, pada 1943 sisa-sisa tahanan politik di Boven Digul dipindahkan ke Australia. Belanda takut bahwa para tahanan politik itu akan dibebaskan dan dimanfaatkan oleh bala tentara Jepang.

\section{CATATAN}

${ }^{1}$ Margaret J. Kartomi menyebutkan bahwa sekolah setingkat HIS dibuka di Tanah Merah pada akhir tahun 1927. Guru yang mengajar di sekolah ini mendapatkan tambahan penghasilan $\mathrm{f} 0,75$ per hari.

${ }^{2}$ Wawancara dengan Trikoyo (83 tahun) pada 3 November 2010, dan dengan Siti Chamsinah (84 tahun) 7 Desember 2010.

${ }^{3}$ Catatan pemerintah Belanda tentang Soetan Said Ali yang menjadi anggota PKI di Sumatra Barat. Dalam catatan itu dinyatakan bahwa ia berangkat ke Jawa dan kemudian kembali ke Medan pada 20 November 1925. Dimuat dalam "Overzicht van de Politieke toestand ter Sumatera's Westkust aansluitende op het overzicht ddo. 5 April 1927: Kort overzicht van geschiedenis der PKI ter Sumatra's Westkust" dalam ANRI, "Arsip Binnenlandsch-Bestuur", No. 215.

${ }^{4}$ Siti Chamsinah menyebut dua nama ini dalam wawancaranya. Jahja Nasoetion kemudian menjadi suaminya. Keduanya menikah di Australia, di mana kelompok terakhir penghuni kamp Boven Digul ditempatkan setelah Jepang masuk, dan keduanya kembali ke Indonesia pada 1946. Wawancara dengan Siti Chamsinah pada 11 Desember 2010. Trikoyo dan Chamsinah adalah anak-anak yang tumbuh dewasa di Boven Digul. Keduanya merasakan praktik pendidikan di tempat itu. Trikoyo lahir di Grabag (Kutoarjo) pada 29 Februari 1926. Ketika berangkat ke Boven Digul usianya belum genap 1 (satu) tahun. Keluarga ini berada di Boven Digul sampai pada 12 Juli 1940. Trikoyo sekeluarga dikirim ke Boven Digul, karena ayahnya yang pemimpin pondok pesantren di Grabag Kutoarjo tidak mau menerima bantuan dari pemerintah Belanda. Pesantrennya dituduh antiBelanda dan komunis. Awalnya, Trikoyo bersekolah di MES, tetapi kemudian masuk ke Standaardschool ketika ayahnya tidak lagi menjadi naturalis. Dia menamatkan pendidikan setingkat di Standaardschool tujuh tahun di Boven Digul. Pada Mei 1940, Trikoyo sekeluarga pulang, kecuali ayahnya, dan tinggal bersama kakeknya, Abdoel Djalal, di Kutoarjo. Ayahnya berangkat ke Australia, kemudian Trikoyo ikut pamannya ke Pontianak, Kalimantan Barat, yang sudah bekerja di perusahaan perkebunan Jepang. Pada masa pendudukan Jepang, Trikoyo mengikuti pendidikan militer Jepang di Kalimantan Utara. Ketika Jepang kalah, ia bersama 40 orang eks-Heiho yang berasal dari Jawa lari ke Kalimantan Barat. Mereka 
membentuk pasukan perlawanan terhadap pasukan Sekutu dan Belanda.

Saksi hidup di kamp Boven Digul yang lain adalah Siti Chamsinah, yang lahir pada September 1926, dan ikut ke Boven Digul pada usia dua tahun, tepatnya pada 1928. Ayahnya yang aktif dalam dunia pergerakan sering dikejar-kejar oleh pemerintah kolonial Belanda, dan sempat dipenjara selama dua tahun sebelum akhirnya diasingkan ke Boven Digul. Chamsinah bertemu dengan ayahnya di kapal menjelang berangkat ke Boven Digul. Dalam hal pendidikan, Chamsinah awalnya hanya dua tahun mengenyam pendidikan di Standaardschool. Pada waktu itu para tahanan membuat sekolah sendiri di kampung B. Chamsinah dipindahkan ke sekolah itu. Di sekolah yang baru, pelajaran diajarkan dengan menggunakan bahasa Melayu dan Inggris. Dia berada Boven Digul sampai pada usia 17 tahun. Setelah kamp Boven Digul ditutup, Chamsinah dan sisa-sisa tahanan yang lain dipindahkan ke Australia. Selama menunggu keberangkatan ke Australia, Chamsinah dan rombongan mendapat suplai makanan dari Sekutu. Ada sekitar 300 orang dikirim ke Australia. Dengan kapal terbang mereka dibawa ke Thursday Island, setelah 14 hari mereka menuju Brisbane dengan kapal, dan ke Cowra dengan kereta api. Mereka tinggal di situ selama 9 bulan. Chamsinah ke Melbourne untuk sekolah lagi dengan 5 (lima) orang teman wanita. Abangnya dengan 8 (delapan) orang temannya juga ikut. Chamsinah masuk sekolah perawat. Abangnya dan teman-temannya dijadikan angkatan udara Belanda. Setelah satu tahun sekolah, pemerintah Belanda memintanya untuk bekerja di rumah sakit Belanda di Hollandia, tetapi ditolaknya. Apabila menolak, pemerintah Belanda tidak menanggung biaya sekolah dan harus kembali ke orang tua. Waktu itu orang tuanya ada di Australia Utara. Chamsinah kembali ke rumah orang tuanya. Chamsinah menikah di tempat itu dan kembali ke Indonesia pada 1946.

${ }^{5}$ Nama ini disebut oleh Trikoyo sebagai wakil kepala sekolah di Standaardschool, ketika dia bersekolah. Wawancara dengan Trikoyo pada 3 November 2009.

${ }^{6}$ Tidak diketahui pasti gaji itu merupakan gaji bulanan atau tahunan. Dalam laporan yang ditulis pada 1 Maret 1932 hanya disebut jumlah itu. Periksa dalam ANRI, “Arsip Boven Digoel 1927-1942 dan 1954”, No. 46.

${ }^{7}$ Standaardschool menurut Jan Aritonang adalah nama baru untuk sekolah kelas dua. Sekolah kelas dua merupakan peningkatan kualitas dari sekolah desa (volksschool) yang berdiri di banyak desa (Jawa), yang awalnya bertujuan sekadar untuk memberantas buta huruf. Pelajarannya hanya pengetahuan dasar bacatulis-hitung, dengan lama belajar selama tiga tahun. Periksa Staatsblad tahun 1906 No. 241 dan No. 242.

${ }^{8}$ Informasi tentang aktivitas persekolahan pada masa awal beroperasinya kamp Boven Digul diperoleh dari Pandji Poestaka No. 53, 2 Juli 1929, Tahoen VII, hlm. 837.

${ }^{9}$ Menurut kesaksian Siti Chamsinah, peristiwa bermula dari acara peringatan "Hari Buruh" pada $1 \mathrm{Mei}$, yang diikuti oleh hampir semua penghuni kamp. Ketika salah seorang dari mereka sedang berpidato, tiba-tiba polisi datang tanpa alasan yang jelas dan membubarkan acara tersebut. Polisi mengamankan mereka yang dianggap bertanggung jawab pada acara itu. Wawancara dengan Siti Chamsinah pada tanggal 7 Desember 2010.

${ }^{10}$ Kasus itu menimpa Suroso, yang diadukan oleh anggota ROB karena telah mengajar lebih dari tiga orang anak. Ketika ia mengajar bola basket kepada lebih dari tiga orang anak, maka pemerintah memenjarakannya selama satu hari.

11"Opgave van leerlingen en onderwijzer van naturalisten op ultimo $2^{\text {e }}$ kwartaal 1939", Inventaris Arsip Boven Digoel No. 317 (ANRI-Jakarta)

12“"Leerlingen van Kadarisman Stb. 66," dalam Arsip Boven Digoel 1927-1942\&1954, No. 317.

13" Opgave leerlingen van wilde schoolen e.a. over het tweede kwartaal 1941", dalam ANRI, "Arsip Boven Digoel 1927-1942 dan 1954", No. 319.

14"Standaardschool met Nederlandsch", dalam ANRI, “Arsip Boven Digoel 1927-1942\&1954”, No. 319.

${ }^{15}$ Lihat, "Opgave van leerlingen en onderwijzers van naturalisten op ultimo $2^{\text {de }}$ kwartaal 1939", dalam ANRI, “Arsip Boven Digoel 1927-1942\&1954”, No. 317.

16“ Opgave van leerlingan en onderwijzers van naturalisten op ultimo $3^{\text {de }}$ kwartaal 1939," dalam Arsip Boven Digoel 1927-1942 \& 1954, No. 317.

17" Opgave van leerlingan en onderwijzers van naturalisten op ultimo $4^{\text {de }}$ kwartaal 1939," dalam ANRI, “Arsip Boven Digoel 1927-1942\&1954”, No. 317.

18 "Opgave van leerlingan en onderwijzers van naturalisten op ultimo $1^{e}$ kwartaal 1939," dalam ANRI, “Arsip Boven Digoel 1927-1942 \& 1954”, No. 318.

19" $2^{\text {de }}$ kwartaal 1940 opgave leerlingen $\mathrm{v} / \mathrm{d}$ wilde scholen", dalam ANRI, "Arsip Boven Digoel 19271942 \& 1954”, No. 318 .

${ }^{20}$ ANRI, “Arsip Boven Digoel 1927-1942 \& 1954”, No. 319. 
${ }^{21}$ Lihat Dagboek Pol.Int.25/9-'35 t/m 15/2-'36, ANRI, “Arsip Boven Digoel 1927-1942 \& 1954”, No. 211.

${ }^{22}$ Wawancara dengan Trikoyo pada 3 November 2009.

${ }^{23}$ Wawancara dengan Trikoyo pada 7 Desember 2010, dan dengan Siti Chamsinah pada 7 Desember 2010.

${ }^{24} \mathrm{Hal}$ itu disampaikan kedua saksi sejarah tersebut dalam wawancara pada 7 Desember 2010.

${ }^{25}$ Wawancara dengan Trikoyo dan Chamsinah pada 7 Desember 2010. Chamsinah dapat menyaksikan cara berkomunikasi antara keluarganya dengan penduduk asli, sebab keluarganya memiliki satu orang pembantu penduduk asli Papua.

\section{REFERENSI}

ANRI, “Arsip Binnenlandsch-Bestuur 1927-1942, 1954”, No. 215.

ANRI, “Arsip Boven Digoel 1927-1942, 1954”, No. 317.

ANRI, “Arsip Boven Digoel 1927-1942, 1954”, No. 318.

ANRI, “Arsip Boven Digoel 1927-1942, 1954”, No. 319.

ANRI, “Boven Digoel 1927-1942, 1954”, No. 211.

ANRI, “Boven Digoel 1927-1942, 1954”, No. 46.

Aritonang, Jan. S. (1988). Sejarah Pendidikan Kristen di Tanah Batak: Suatu Telaah Historis-Teologis Atas Perjumpaan Orang Batak dengan Zending (khususnya RMG) di Bidang Pendidikan, 1861-1940. Jakarta: BPK Gunung Mulia.

Bondan, Molly (2008). Spanning a Revolution: Kisah Mohamad Bondan, Eks-Digulis, dan Pergerakan Nasional Indonesia. Jakarta: Yayasan Obor Indonesia.

De Jong, L. (2002). The Collapse of a Colonial Society: the Dutch in Indonesia during the Second World War. Leiden: KITLV Press.

Elson, R.E. (2009). The Idea of Indonesia: Sejarah Pemikiran dan Gagasan. Terjemahan Zia Anshor. Jakarta: Serambi Ilmu Semesta

Furnivall, J.S. (2009). Hindia Belanda: Studi tentang Ekonomi Majemuk. Terjemahan Samsudin Barlian. Jakarta: Freedom Institute.
Groeneboer, Kees (1995). Jalan ke Barat: Bahasa Belanda di Hindia Belanda, 1600-1950, Sejarah Politik Bahasa. Terjemahan Jessy Augusdin. Jakarta: Erasmus Taal Centrum.

Hadler, Jeffrey (2010). Sengketa Tiada Putus: Matriarkat, Reformisme Agama, dan Kolonialisme di Minangkabau. Terjemahan Samsudin Berlian. Jakarta: Freedom Institute.

Kahin, George McT. (1990). Molly Bondan: 1912-1990. Indonesia, No. 50.

Kartodirdjo, Sartono (1990). Pengantar Sejarah Indonesia Baru: Sejarah Pergerakan Nasional dari Kolonialisme sampai Nasionalisme. Jilid 2. Jakarta: PT. Gramedia.

Kartodirdjo, Sartono (1993). Ilmu Sosial dalam Metodologi Sejarah. Jakarta: PT. Gramedia Pustaka Utama.

Kartomi, Margaret J. (2005). Gamelan Digul: di balik Sosok Seorang Pejuang: Hubungan antara Indonesia dengan Australia. Terjemahan Hersri Setiawan. Jakarta: Yayasan Obor Indonesia.

Lockwood, Rupert (1983). Armada Hitam. Terjemahan Koesalah Soebagijo Toer. Jakarta: PT. Gunung Agung.

Nordholt, Henk S., Purwanto, B., dan Saptari, R. (ed.) (2008). Perspektif Baru Penulisan Sejarah Indonesia. Jakarta-Denpasar: Yayasan Obor Indonesia, KITLV, Pustaka Larasan. Pandji Poestaka, No. 53, 2 Juli 1929, Tahoen VII. Pranoto, Suhartono W. (2010). Teori dan Metodologi Sejarah. Yogyakarta: Graha Ilmu.

Shiraishi, Takashi (2001). Hantu Digoel: Politik Pengamanan Politik Zaman Kolonial. Terjemahan Endi Haryono, Nicolaus Loy, dan Nur Khoiron. Yogyakarta: LKiS.

Staatsblad van Nederlandsch-Indie 1893, No. 125. Sudiri Panyarikan, I Ktut (1996). "Sejarah Pendidikan di Indonesia: Jenjang Pendidikan Dasar pada Jaman Hindia Belanda Tahun 1900-1942”, Forum Penelitian Kependidikan Th. 8 , Desember.

Tsuchiya, Kenji (1992). Demokrasi dan Kepemimpinan: Kebangkitan Taman Siswa. Terj. H.B. Jassin. Jakarta: Balai Pustaka. 
Jurnal Sejarah Citra Lekha, Vol. 2 , No. 2, 2017, hlm. 112-125

\section{Wawancara}

Trikoyo ( 83 tahun) pada 3 November 2010.

Siti Chamsinah (84 tahun) pada 7 Desember 2010. 